\title{
Recovery of Deep-sea Meiofauna after Artificial Disturbance in the Central Indian Basin
}

\author{
INGOLE B.S*., R. GOLTEKAR, S. GONSALVES and Z. A. ANSARI \\ Biological Oceanography Division, \\ National Institute of Oceanography, Dona Paula, \\ Goa; 403004, INDIA.
}

\begin{abstract}
Colonization of deep-sea (5000-5500-m depths) metazoan meiofaunal assemblage (in terms of abundance and community structure) were investigated in the Central Indian Ocean Basin (ClOB), immediately after and also 44 months after a benthic disturbance experiment. The abundance of nematodes, which are normally dominating the deep-sea meiofauna, was reduced (by $50 \%$; $p<0.001$ ) in post-disturbance. The density of meiofauna was generally low during the monitoring phase and varied moderately inside and outside the test area (experimental site). The density values ranged from 8 and 52 no. $10 \mathrm{~cm}^{-2}$ (mean: $23.5 \pm 12.2 \mathrm{SD} ; \mathrm{n=12}$ ) in the impacted area. There was steady buildup in nematode population in the test area between the experiment and the monitoring observations 44 months later, as compared to other metazoan density. Meiofauna were vertically recorded down to $30-35-\mathrm{cm}$ sediment layer during the monitoring. Although, bulk of meiofauna (80\%) occurred in top $20 \mathrm{~cm}$ sediment layer of reference area, only $16 \%$ of the fauna was observed in $0-2 \mathrm{~cm}$. On the contrary, $>30 \%$ metazoan population occurred in $0-2 \mathrm{~cm}$ section in the test area. Bringing up nutrients from sub-surface and depositing this organically rich material on the sediment surface, could have acted as a stimulating factor for meiofaunal recovery as most of the meiofauna feed on bacteria and dead organic material (DOM). This experimental study suggests that whereas on one hand commercial mining of the deep-sea mineral resources may affect deep-sea benthic communities immediately after the impact, on other hand, availability of food material due to turn over (similar to plowing) of sediments may help recolonisation at temporal scale.
\end{abstract}

Keywords: Sediment disturbance, meiofauna, restoration, Central Indian Ocean.

*Corresponding author: baban@nio.org 


\section{Introduction}

The deep sea floor is known to harbour high biodiversity of benthic fauna (Grassle and Maciolek, 1992; Rex et al., 1993). The temperature, salinity and dissolved oxygen content fluctuate within a very narrow range at abyssal depths, where food availability is limited (Pfannkuche, 1993). The benthic community appears to be adapted to the prevailing conditions at deep sea and any disturbance to their environment could bring changes in the density, diversity and distribution.

As the larger organisms (such as macro- and megafauna) are relatively less on the deep-sea floor, the smaller size class (such as meiofauna) becomes more important (Thurston et al., 1998). The meiofauna constitute an important component of the deep-sea benthos, as they not only act as food material for larger macro- and megabenthic species but also play an important role in making detritus available to macroconsumers (Thiel 1993; Tenore et al., 1977). However, their composition and abundance are limited by availability of food (Thiel, 1983). The labile organic constituents of the deep-sea sediment play a significant role in meiofaunal food (Tietjen 1971; Ingole et al., 1992; Danovaro et al., 1993; Shirayama and Fukushima, 1997; Raghukumar et al., 2001). The growth of bacteria in deep-sea sediments depends upon the availability of dissolved organic carbon in sediment pore water; particulate organic carbon derived from faecal matter of benthos and detritus derived from dead benthos. Thus, bacterial and benthic biomass is tightly coupled in deep-sea sediments (Alongi and Pichon, 1988; Ragukumar et al 2001). Nevertheless, changes in natural conditions due to manmade disturbance in the benthic environment may upset this equilibrium.

To assess the possible effects of future commercial deep-sea mining of manganese nodules on the benthic communities, a benthic disturbance experiment was conducted in the Central Indian Ocean under the Indian Deepsea Environmental Experiment (INDEX). The seafloor bottom was physically disturbed by moving a benthic disturber in a $3000 \mathrm{~m}$ long x $200 \mathrm{~m}$ wide area. 
Sharma (2001) described the location and characteristics of the test and reference site as well as experimental design and procedures followed. The immediate response of benthic community to sediment disturbance indicated a significant $\approx 40 \%$ reduction in the benthic population at taxon as well as community levels (Ingole et al., 2000; 2001). The present investigation is a part of the monitoring phase of the INDEX programme conducted 44 months after initial disturbance. The purpose of this study is to assess the influence of physical disturbance, on the lateral and vertical distribution of meiofaunal communities in different phases of INDEX experiment. Accordingly, we tested the hypothesis that movements of mining instrument on the seafloor not only diminish the meiofaunal population but also modify the pattern of their spatial and vertical distribution.

\section{Materials and Methods}

This study is based on the benthic samples collected on two Russian research vessels R.V. Yuzhmorgeologia and R.V.A.A. Sidorenko in the polymetallic nodule field within the Central Indian Ocean Basin. Deep-sea sediment sampling was conducted prior to benthic disturbance (i.e., in June 1997, termed as predisturbance sampling) and immediately after the disturbance in August 1997 (termed as post-disturbance). In order to monitor the recolonisation and restoration of the deep-sea environment, another set of observations were made in April 2001 in the test and reference sites. Conductivity Temperature Density (CTD) profile, taken in the vicinity of the area, indicated that temperature decreased from about $32^{\circ} \mathrm{C}$ at surface to $-2^{\circ} \mathrm{C}$ below $4500 \mathrm{~m}$ depth (Murthy et al., 2001). Salinity profiles showed a superficial thin layer of high salinity at bottom water layer (34.72 PSU at 3000m depth; Murthy et al., 2001). To study the process of meiofaunal recolonisation, benthic samples were taken with the

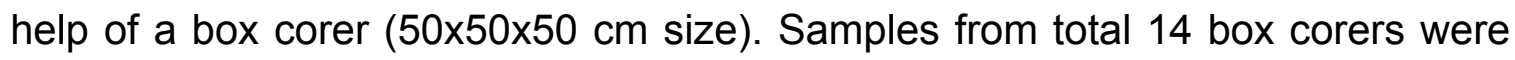
analyzed; 12 from the test site and 2 from the reference site. Details of the sampling location and sediment characteristics are given in table 1 and figure 1. Sub-samples (2-3 replicates) for meiofauna were taken by inserting an acrylic 
core tube (inner diameter $5.7 \mathrm{~cm}$ ) in the box core (plate 1). The core tube was capped and the uppermost 2-cm thick sediment layer was carefully sectioned at $0.5-\mathrm{cm}$ intervals, followed by $2-\mathrm{cm}$ intervals sections down to $20 \mathrm{~cm}$ core depth and rest of the core was sectioned at $5-\mathrm{cm}$ intervals. Each sub-section was processed separately, which involves fixation in 5\% formalin- Rose Bengal solution. In the laboratory, the samples were washed through a series of different mesh size sieves (500, 63 and $45 \mu \mathrm{m}$ ), sorted and identified under stereoscopic binocular microscope. Metazoan meiofauna in this paper is defined as organisms passing through a $500 \mu \mathrm{m}$ sieves and retained on $45 \mu \mathrm{m}$ sieves.

Statistical analysis was performed using the general linear model method of least squares, the T-test and the Mann-Whitney a-parametric test. One-way analysis of variance (ANOVA) was used to test differences in meiofaunal density between experimental (test) and reference sites as well as differences between the pre-and post-disturbance and monitoring phase. All the tests were performed under the assumption of $95 \%$ confidence level.

\section{Results}

\section{Composition and abundance}

The study area has siliceous ooze sediments and low ferromanganese nodules abundance $\left(<2 \mathrm{~kg} / \mathrm{m}^{2}\right.$; Sharma, 1999). The meiobenthic assemblage was made up of 8 metazoan groups. The depth integrated average abundance in the test area varied between 8 and 52 meiofauna per $10 \mathrm{~cm}^{2}$ (mean: $23.5 \pm 12.2 \mathrm{SD}$; $\mathrm{n}=12$; Table 2). Meiofaunal counts in individual cores varied from 28-37 no.10 $\mathrm{cm}^{-2}$ and 8-52 no.10 $\mathrm{cm}^{-2}$ inside (stns. 2,3 and 5) and outside (all other stns. shown in Table 2) of the test area (Fig. 2). Nematodes were numerically the most abundant taxa with a relative abundance of $37 \%$ of the total number collected from the test area (Table 3). They were followed by nemertin worms, turbellarians, gastrotrichs, polychaetes and harpacticoid copepods with a relative abundance of $35 \%, 11 \%, 9 \%, 4 \%$ and $1 \%$, respectively (Table 3 ). Mean abundance of nematodes and nemertines, was $12.0 \pm 9.6$ SD $(n=7)$ and 11.3 
\pm 10.2 SD ( $n=7)$, respectively. Nematode density was slightly higher in the test area compared to reference.

\section{Vertical distribution of meiofauna in the sediment column}

The vertical distribution of meiofauna in the sediment column was expressed as total counts and percentage (\%) in the respective sediment section. Differences between abundance and vertical distribution at different sites (test and reference) are given separately in Table 2 and figure 3. It shows that, the vertical profile of meiofauna in the sediment column differed considerably, especially in the top 0-2 $\mathrm{cm}$ layers. In the test area, metazoans were distributed down to the sediment depth of $35-40 \mathrm{~cm}$, although, $>60 \%$ of the population was recorded in top $10-\mathrm{cm}$ layer, $>30 \%$ fauna was found in the uppermost $0-2 \mathrm{~cm}$ section (Fig.3A). However, only $16 \%$ of the metazoan population was observed in the same section $(0-2 \mathrm{~cm})$ of reference area (Fig.3B). The cumulative frequency (\%) of specimens down to a sediment depth of $35-40 \mathrm{~cm}$ in test and reference area is shown in figure 4 . It indicated that a bulk of meiofauna (80\%) occurred in the top $20 \mathrm{~cm}$ sediment layer of reference area, only $10 \%$ of the fauna was observed in top 0-2 cm. In case of the test area, $>30 \%$ metazoan population occurred in $0-2$ $\mathrm{cm}$ and accumulative value of $90 \%$ occurred at the sediment depth of $30 \mathrm{~cm}$. This indicates that metazoan concentration was much higher in the uppermost sediment layer of test area.

\section{Comparison with pre- and post-disturbance study}

The comparison of the depth integrated meiofauna abundance on the test and reference area during monitoring phase to that of pre- and post-disturbance phase is given in figure 2 and 5 . The density of meiofauna was decreased from 45 no. $10 \mathrm{~cm}^{-2}$ to $21 \mathrm{no} .10 \mathrm{~cm}^{-2}$ in post-disturbance and maximum reduction was in the test area (stn. 2,3, \& 5; Fig.2 \& 5). The monitoring study conducted after 44 months, showed wider variation in mean meiofaunal density with overall increase not only in the test area (stn.2, 3 and 5; Fig.2) but also in either side of the test area (Fig.5). The nematode: copepod (N:C) ratio which was increased from 2.18 (pre-disturbance) 3.00 in post-disturbance was depressed towards copepods 
showing further increase to 30.0. Two-way ANOVA showed showed significant variation in mean meiofaunal density between and within the test as well as reference area (Table 5).

\section{Discussion}

The distribution of meiofauna in the sediment column did not show consistence pattern and the values differed considerably between the sampling locations. During the pre-disturbance study, majority $(>75 \%)$ of the meiofauna was concentrated in the upper most sediment layer and a similar pattern of vertical disturbance was observed during the post-disturbance (Ingole 2000). However, there was considerable $(40 \%)$ reduction in the total meiofaunal density in the top 2-3 cm sediment layer in post disturbance. Deep-sea meiofauna generally concentrated to a relatively thin surface layer of the sediment (Ingole et al., 1992; Shirayama and Fukushima, 1997; Radziejewska and Modlitba, 1999). Although meiofaunal organisms were vertically distributed down to $30-35 \mathrm{~cm}$ layers at both the sites, only $10 \%$ population lived in the $0-2 \mathrm{~cm}$ layer of the reference area. On the other hand almost $>30 \%$ population was recorded in top $0-2 \mathrm{~cm}$ sediment layer of test area. Considerable difference in the vertical distribution of meiofauna observed in the top 0-2 cm layer of test and reference area (Fig. 3 A \& B) was due to the physical disturbance. In earlier studies, Pfankuche and Thiel (1987) and Ingole et al (1992) reported $90 \%$ and $70 \%$ of metazoan population from 0-2 $\mathrm{cm}$ sediment layer, respectively from Arctic Ocean (Nansen Basin) and southwestern Indian Ocean (Rodrigues and Saya de Malha Bank). Thus, the physical disturbance conducted in the CIB 44 months prior to the present sampling, may have created entirely new conditions in the deep-sea environment, such as bringing up dissolved nutrients from the subsurface layers and depositing the organically rich sediment layer on sediment surface (Ingole et al., 1999; (Ragukumar et al., 2001; Nath et al., 2005). It is believed that the sediment disturbance at deep-sea level is deleterious to the buried in-fauna; however it increases the food resources for larger epibenthic animals by exposing the organically rich sediment to the surface (Bluhm, 1994; Ingole et al., 
2002). The increased meiofaunal population on the test as well as in the adjacent area (Fig.5) therefore, was mainly due to the augmented food supply (Raghukumar et al., 2002; Nath et al., 2005). Nevertheless, occurrence of some portion of meiofaunal population in deeper layer of some of the sediment cores collected during the monitoring phase (Table 2), strongly suggested a possible influence of higher sediment reworking by larger macro-and megabenthic organisms (Soetaert et al., 1997; Nath et al., 2005). Presence of live polychaete burrows as deep as $25 \mathrm{~cm}$ (Ingole et al., 2005); further support the fresh bioturbation activity in the sediment layer, both in the reference as well as test area. During the pre- and post-disturbance study, sediment samples were collected down to $20 \mathrm{~cm}$ sediment depth; however meiofauna was not present below $12 \mathrm{~cm}$. In the monitoring phase, cores were collected down to sediment depth of $40 \mathrm{~cm}$ and meiofauna was observed till $30-35 \mathrm{~cm}$ (Table 2; fig.3). The occurrence of fauna to the deeper sediment depths $(>30 \mathrm{~cm})$ could be as a consequence of increased sediment porosity and permeability (Rardziejewska and Modlitba, 1999).

The vertical distribution of meiofauna at reference area (Fig. 3 B) showed totally different pattern, particularly for the top few centimeters, which is very critical for deep-sea meiofauna (Shirayama and Fukushima, 1997) and did not agree with the general pattern reported for the Indian Ocean (Ingole et al., 1992). It probably suggests a wider impact of physical disturbance on sedimentation in CIB and agrees with the observations of Valsangkar (2004). Discussing the results of German deep-sea disturbance experiment, DISCOL Schriever et al, (1997) have also reported the enhanced meiofaunal population at reference area. This indicates that certain processes take place in the abyssal communities even without human interference, supporting the notion of no absolute inherent stability on the abyssal seafloor (Gage and Tyler, 1991). Sporadic flux of phytodetrital material, which sinks from the euphotic zone to the deep-sea floor, is perhaps liable for instability of deep-sea fauna (Galeron et al., 2001 and references there in). 
The meiofaunal abundance observed in the Central Indian Basin fall within the reported range from the deep-sea areas of Indian Ocean (Parulekar et al.,1992; Ingole et al., 1992) and from similar depths in Pacific Ocean (Shirayama and Fukushima, 1997; Rardziejewska and Rokicka-Praxmajer, 2001). Nematodes and copepods showed differences between samples collected before and immediately after the disturbance (Ingole et al., 2000). The nematode: copepod $(\mathrm{N}: \mathrm{C}$ ) ratio frequently used as environmental indicator (Warwick, 1981; Danovaro et al., 1995; Ingole et al., 2000; Kim et al., 2000; Ansari and Ingole, 2002) was used to assess the restoration process.

As shown in table 4, the values were depressed towards harpacticoid copepods from 2.18 in pre-disturbance to 3.00 in post-disturbance suggesting that copepods are less resistant to sediment disturbance. This ratio was further depressed towards copepods in monitoring phase (30); indicate the steady recovery of nematodes. Hence, harpacticoid copepods being the second dominant metazoan group during pre-disturbance, were not recovering at the same rates to that of nematodes. These micro-crustaceans are considered very sensitive to environmental changes (Raffaelli and Mason, 1981), whereas nematodes are resistant to the rapidly changed environment (Heip, 1980; Moore and Bett, 1989; Ansari and Ingole, 2002). On the other hand, nemertine worms emerged as second dominant group next to nematodes, during the monitoring phase (Table 3). These proboscis worms were not observed during pre- and post-disturbance phase and their dominance over predictable deep-sea meiofaunal taxon during the monitoring phase was conspicuous. However, as majority of nemertine worms are carnivorous (McDermott and Roe, 1985), their dominance after 44 months could be due to the availability of abundant food material. Hence, the disturber activity provided a suitable habitat for colonization of certain exceptional forms such as nemertine worms, by stimulated production of their food material and thus increasing their population. Nevertheless, this aspect needs further detailed analysis and therefore, the results on emergence of nemertines should be interpreted cautiously. 
It is anticipated that the physical disturbance at deep-sea level may have mixed impact on the benthic biota (Dayton and Hessler, 1972). The experimental studies conducted in the CIB suggest that whereas on one hand deep-sea disturbance as in case of mining of the deep-sea mineral resources will affect deep-sea benthic communities immediately after the impact (Foell et al., 1990; Shirayama and Fukushima, 1997; Rardziejewska, 1997; Shriever et al., 1997; Ingole et al., 1999; 2000; Radziejewska and Stoyanova, 2000; Radziejewska and Rokicka-Praxmajer, 2001); on the other hand, their recovery is expected to be slow. However, availability of food due to mining of sediments may help recovery and fast recolonisation of benthic fauna.

\section{Acknowledgements}

The authors wish to thank the Director, NIO, Goa for the facilities. We are grateful to the officers and crew of the research vessels for their help in on board sample collection. Thanks are also due to Dr. Rahul Sharma for reading the draft and suggestions. This study was carried out as a part of "Environmental Impact Assessment of nodule mining in the Central Indian Basin' funded by Department of Ocean Development (Govt. of India). This is NIO contribution No...... 


\section{References}

Alongi, D.M., Pichon, M. ,1988. Bathyal meiobenthos of the western Coral Sea: distribution and abundance in relation to microbial standing stocks and environmental factors. Deep-sea Research 35(4): 491-503.

Ansari, Z. A., 2000. Distribution of deep-sea benthos in the proposed mining area of Central Indian Ocean. Marine Georesource and Geotechnology 18(3): 201-207.

Ansari, Z. A., Ingole, B. S., 2002. Effect of a Spill of Fuel Oil on the meiofauna of a Sandy beach at Goa, Central west coast of India. Marine Pollution Bulletin 44:396-402.

Danovaro, R., Fabiano, M., Albertelli, G., Della Croce, N., 1993. Vertical distribution of meiobenthos in abthyal sediments of the eastern Mediterranean Sea: relationship with labile organic matter and bacterial biomasses. P.S.Z.N.I. Marine Ecology 16:103-116.

Danovaro, R., Fabiano, M., Vinex, M., 1995. Meiofaunal response to the Agip Abruzzo oil spill in subtidal sediments of the Ligurian Sea. Marine Pollution Bulletin 30(2):133-145.

Danovaro, R., C. Gambi., N. Della Croce, 2002, Meiofauna hotspot in the Atacama Trench, eastern South Pacific Ocean. Deep-sea Research I 49:843857.

Foell, E.J., Thiel. H, Schriever, G., 1990. "DISCOL: A long-term large scale, disturbance recolonisation experiment in the abyssal Eastern Tropical South Pacific Ocean". Offshore Technology Conference (Houston, USA), no. 6328: 497-503.

Galeron, J., Sibuet, M., vanreusel, A., Mackenzie, K., Gooday, A.J., Dinet, A., Wolff, G.A., 2001. Temporal patterns among meiofauna and macrofauna taxa related to changes in sediment geochemistry at an abyssal NE Atlantic site. Proress in Oceanography 50:303-324.

Grassle, J.F., Maciolek,N. J., 1992. Deep-sea species richness: regional and local diversity estimates from quantitative bottom sampling. American Naturalist 139:313-341.

Heip, C. 1980. Meiobenthos as a tool in the assessment of marine environmntal quality. Rapp. P.V. Reun.Cons.Int.Explor.Mer.179:182-187.

Ingole, B.S., Ansari, Z.A., Parulekar, A.H., 1992. Benthic fauna around Mauritius island:Southwest Indian Ocean. Indian Journal of Marine Science 21:268-273. 
Ingole, B.S., Ansari, Z.A., Matondker, S.G.P., Rodrigues, N., 1999. Immediate response of meio and macrobenthos to disturbance caused a benthic disturber. Proceedings of the third ISOPE-Ocean Mining Symposium, N.I.O Goa, pp. 191197.

Ingole B.S., Ansari Z.A, Rathod, V., Rodrigues, N., 2000. Response of meiofauna to immediate benthic disturbance in the Central Indian Ocean. Marine Georesource and Geotechnology 18(3):263-272.

Ingole B.S., Ansari Z.A., Rathod, V., Rodrigues, N., 2001. Response of Deep-sea macrobenthos to a small-scale environmental disturbance. Deep-sea Research II, 48, 3401-3410.

Jianxin, X., Ning, Y. 1999. Fundamental estimation of suspended tailings discharge during manganese nodule mining. Proceedings of the third ISOPEOcean Mining Symposium, N.I.O Goa, pp.152-155.

Kim, D., Je, J., Lee, J. 2000. The community structure and spatial distribution of meiobenthos in the Kanghwa, tidal flat, west coast of Korea. Ocean Research 22(1):15-23.

Nath, B.N, Nabar, S., Ingole, B. S. Khadge, N. H., Valsangkar, A. B., Srinivas, K., Nair, S. Raghukumar, C., 2005. Geochemical changes induced by Benthic disturbance Experiment in the Central Indian Basin: Organic carbon dynamics. (Communicated)

Motohiro, S, and Y. Shirayama., 2003. Sex ratio and reproductive activity of benthic copepods in baythal Sagami Bay $(1430 \mathrm{~m})$, Central Japan. Progress in Oceanography 57:97-107.

Moore, C. G., Bett, B. J., 1989. The use of meiofauna in marine pollution impact assessment. Zoological Journal of Linnus Society $96: 263-280$.

Pfannkuche, O., 1993. Benthic response to the sedimentation of particulate organic matter at the BIOTRANS station, 470 N, 200 W. Deep-sea Research II 40(1/2):135-149.

Raffaelli, D., Mason, C. F. 1981. Pollution monitoring with meiofauna, using the ratio of nematodes to copepods. Marine Pollution Bulletin 12:158- 163.

Rardziejewska T, 1997. Immediate responses of benthic meio- and megafauna to disturbance caused by polymettalic nodule miner simulator. International Symposium on environmental studies for Deep-sea mining pp. 223-235.

Rardziejewska T., Modlitba, I., 1999. Vertical distribution of meiobenthos in relation to geotechnical properties of deep-sea sediments in the IOM pioneer area (Clarion-Clipperton Fracture Zone, NE Pacific). Proceedings of the third ISOPE-Ocean Mining Symposium, NIO, pp.126-130. 
Rardziejewska T., Stoyanova, V., 2000. Abyssal epibenthic megafauna of the Clarion-Clipperton (NE Pacific): changes in time and space versus anthropogenic environmental disturbance. Oceanological Studies XXIX (2): 83-101.

Rardziejewska T., J. Rokicka-Praxmajer, 2001. IOM BIE Revisited: meiobenthos at the IOM BIE site 5 years after experimental disturbance. Proceedings of the third ISOPE-Ocean Mining Symposium, Szczecin, Poland, pp.63-68.

Rex, M. A., Stuart, C. T., Hessler, R.R., Allen, J. A., Sanders, H. L., Wilson, G. D. F., 1993. Global-scale latitudinal patterns of species diversity in the deep-sea benthos. Nature 365:636-639.

Rodrigues, N., Sharma, R., Nath, B. N., 2001. Impact of benthic disturbance on megafauna in Central Indian Basin. Deep-Sea Research II, 48, 3411-3426.

Schriever, G., Ahnert, A., Bluhm, H., Borowski, C., Thiel, H., 1997. Results of The large-scale deep-sea environmental impact study DISCOL during eight years of investigation. Proceeding of the Seventh International Offshore and Polar Engineering Conference Honolulu, USA, pp. 438-444.

Sharma R., 1999. Indian deep-sea environment experiment (INDEX): An appraisal. Proceedings of the third ISOPE Ocean Mining Symposium pp.118125.

Sharma R., Nath, B. N., Parthiban, G., Jaisankar, S., 2001. Sediment redistribution during simulated benthic disturbance and its implications on deepsea bed mining. Deep-sea Research II 48: 3363-3380.

Shirayama Y., Fukushima, T., 1997. Responses of a meiobenthos community to rapid sedimentation. International Symposium on environmental studies for Deep-sea Mining, pp. 187-196.

Stackelberg U.V.,1984. Significance of benthic organisms for the growth and movement of manganese nodules, Equatorial North Pacific. Geo Marine Letters $4: 37-42$

Soetaert, K., Vanaverbeke, J., Heip, C., Herman, P.M.J., Middelburg, J.J., Sandee, A., Duineveld, G., 1997. Nematode distribution in ocean margin sediments of the Goban Spur (Northeast Atlantic) in relation to sediment geochemistry. Deep-Sea Research I,44,1671-1683.

Tenore, K.R., Tietjen, J. H., Lee, J.J., 1977.Effect of meiofauna in incorporation of aged eelgrass, Zostera marine, detritus by the polychaete Nephthys incisa. Journal of the Fisheries Research Board of Canada 34:563-567.

Thiel, H., 1983. Meibenthos and nanobenthos of the deep-sea. In : Deep-sea Biology, G. Rowe, editor, John Wiley, New York, pp.217-231. 
Thurston, M. H., Rice, A. L., Bett, B. J. 1998. Latitudinal variation in invertebrates megafaunal abundance and biomass in the North Atlantic Ocean Abyss. Deepsea Research II 45:203-224.

Tietjen,J.H., 1971. Ecology and distribution of deep-sea meiobenthos off North Carolina. Deep-sea Research 18: 941-957.

Trueblood D. D. Ozturgut, E., 1997. The ecological impacts of the joint U.S. Russian experiment. International Symposium on environmental studies for Deep-sea mining, pp. 237-243.

Tkatchenko, G, Rardziejewska, G., Stoyanova, T.,Modlitba, V., Parizek, A. 1996. Benthic impact experiment in the IOM pioneer area: testing for effects of deepseabed disturbance. Symposium on Benthic disturbance and impact studies, Beijing (China), Valsangkar A.B. Clay as indicator of sediment plume movement in deep-sea environment. Current Science 87(12):1747-1751.

Verlaan, P. A., 1992. Benthic recruitment and manganese crust formation on seamounts. Marine Biology 113: 171-174.

Warwick, R.M., Clarke, K. R., 1993. Increased variability as a symptom of stress in marine communities. Journal of Experimental Marine Biology and Ecology 172: 215-226. 


\begin{tabular}{|c|c|c|c|c|}
\hline \multirow{2}{*}{$\begin{array}{c}\text { Station } \\
\text { No. }\end{array}$} & \multicolumn{2}{|c|}{ Geographical position } & \multirow{2}{*}{$\begin{array}{l}\text { Depth } \\
\text { (m) }\end{array}$} & \multirow[t]{2}{*}{ Sediment texture } \\
\hline & Latitude $\left({ }^{0} \mathrm{~S}\right)$ & Longitude $\left({ }^{0} \mathrm{E}\right)$ & & \\
\hline M-2 & $10^{0} 02.311$ & $76^{0} 01.061$ & 5330 & Test area \\
\hline M-3 & 10.03443 & 76.00958 & 5294 & Test area \\
\hline $\mathrm{M}-4$ & $10^{0} 01.497$ & $75^{0} 59.673$ & 5249 & Adjacent to test area \\
\hline M-5 & $10^{0} 01.786$ & $76^{0} 06.120$ & 5306 & Test area \\
\hline M-6 & $10^{0} 02.651$ & $76^{0} 01.625$ & 5311 & Adjacent to test area \\
\hline M-7 & $10^{0} 02.320$ & $76^{0} 00.470$ & 5350 & 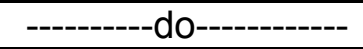 \\
\hline M-8 & $10^{0} 01.788$ & $76^{0} 00.762$ & 5330 & |----------do------------ \\
\hline $\mathrm{M}-12$ & $10^{0} 01.328$ & $76^{0} 00.564$ & 5254 & ----------do------------ \\
\hline $\mathrm{M}-13$ & $10^{0} 01.510$ & $76^{0} 00.350$ & 5286 & -----------do------------ \\
\hline $\mathrm{M}-14$ & $10^{0} 02.200$ & $76^{0} 00.148$ & 5273 & |----------do------------ \\
\hline $\mathrm{M}-15$ & $10^{0} 02.418$ & $75^{0} 59.939$ & 5240 & -----------do------------- \\
\hline $\mathrm{M}-18$ & $10^{0} 02.729$ & $76^{0} 00.620$ & 5315 & -----------do------------- \\
\hline $\mathrm{M}-\mathrm{A} 1 / \mathrm{A}$ & $10^{0} 10.836$ & $75^{0} 22.111$ & 5240 & Reference area \\
\hline $\mathrm{M}-\mathrm{A} 1 / \mathrm{B}$ & $10^{0} 06.873$ & $75^{0} 10.638$ & 5292 & Reference area \\
\hline
\end{tabular}

\begin{tabular}{|c|c|c|c|c|c|c|c|c|c|c|c|c|c|c|}
\hline \multirow{3}{*}{$\begin{array}{l}\text { Sediment } \\
\text { depth }(\mathrm{cm})\end{array}$} & \multicolumn{14}{|c|}{ Station numbers } \\
\hline & \multicolumn{12}{|c|}{ Test area } & \multicolumn{2}{|c|}{ Reference area } \\
\hline & $2 \mathrm{M}$ & $3 \mathrm{M}$ & $4 \mathrm{M}$ & $5 \mathrm{M}$ & $6 \mathrm{M}$ & $7 \mathrm{M}$ & $8 \mathrm{M}$ & $\begin{array}{l}12 \\
M\end{array}$ & $\begin{array}{l}13 \\
M\end{array}$ & $\begin{array}{l}14 \\
M\end{array}$ & $\begin{array}{l}15 \\
M\end{array}$ & $\begin{array}{l}18 \\
M\end{array}$ & $\mathrm{~A} 1 / 1$ & $\mathrm{~A} 1 / \mathrm{B}$ \\
\hline $0-0.5$ & 3 & 3 & 3 & 5 & 4 & 0 & 0 & 3 & 12 & 7 & 2 & 11 & 2 & 1 \\
\hline $0.5-1.0$ & 2 & 2 & 1 & 4 & 4 & 1 & 3 & 1 & 2 & 0 & 1 & 2 & 0 & 2 \\
\hline $1.0-1.5$ & 1 & 2 & 1 & 3 & 3 & 2 & 2 & 0 & 1 & 12 & 0 & 3 & 0 & 2 \\
\hline $1.5-2.0$ & 3 & 2 & 1 & 2 & 2 & 1 & 1 & 0 & 2 & 3 & 0 & 1 & 0 & 1 \\
\hline $2.0-4.0$ & 2 & 1 & 4 & 3 & 4 & 2 & 1 & 0 & 2 & 0 & 4 & 0 & 0 & 2 \\
\hline $4.0-6.0$ & 2 & 2 & 4 & 3 & 3 & 0 & 2 & 0 & 0 & 0 & 2 & 0 & 4 & 1 \\
\hline $6.0-8.0$ & 1 & 1 & 3 & 0 & 3 & 1 & 3 & 0 & 0 & 0 & 0 & 0 & 2 & 1 \\
\hline $8.0-10$ & 2 & 2 & 1 & 1 & 14 & 2 & 1 & 1 & 0 & 0 & 0 & 0 & 1 & 1 \\
\hline $10.0-12$ & 1 & 2 & 1 & 0 & 2 & 2 & 3 & 0 & 0 & 0 & 0 & 0 & 2 & 3 \\
\hline $12.0-14$ & 1 & 1 & 2 & 2 & 3 & 1 & 2 & 2 & 0 & 0 & 0 & 0 & 3 & 1 \\
\hline 14-16 & 2 & 3 & 1 & 3 & 1 & 0 & 1 & 0 & 0 & 0 & 0 & 0 & 1 & 2 \\
\hline $16-18$ & 0 & 1 & 2 & 5 & 3 & 0 & 1 & 0 & 0 & 1 & 0 & 0 & 1 & 5 \\
\hline $18-20$ & 1 & 1 & 1 & 1 & 1 & 1 & 2 & 1 & 0 & 0 & 0 & 1 & 2 & 1 \\
\hline $20-25$ & 2 & 2 & 0 & 2 & 1 & 1 & 1 & 0 & 0 & 0 & 0 & 0 & 2 & 3 \\
\hline $25-30$ & 1 & 1 & 2 & 2 & 1 & 1 & 3 & 0 & 0 & 0 & 0 & 0 & 2 & 1 \\
\hline $30-35$ & 1 & 1 & 1 & 1 & 1 & 0 & 1 & 0 & 0 & 0 & 0 & 0 & 0 & 0 \\
\hline $35-40$ & 3 & 1 & 1 & 0 & 2 & 0 & 3 & 0 & 0 & 0 & 0 & 0 & 0 & 0 \\
\hline $\begin{array}{l}\text { Total } \\
\text { Density }\end{array}$ & 28 & 28 & 29 & 37 & 52 & 15 & 30 & 8 & 19 & 23 & 9 & 18 & 22 & 27 \\
\hline
\end{tabular}




\begin{tabular}{|l|c|c|c|c|c|c|}
\hline \multicolumn{7}{|c|}{ Table,3: Composition (\%) and abundance $\left(\mathrm{no} .10 \mathrm{~cm}^{-2}\right)$ of meiofauna at } \\
test and reference site during monitoring phase.
\end{tabular}

\begin{tabular}{|c|c|c|c|c|}
\hline Taxon/group & $\begin{array}{c}\text { Baseline } \\
\text { study } \\
(1996)\end{array}$ & $\begin{array}{c}\text { Pre- } \\
\text { disturbance } \\
\text { (June 1997) }\end{array}$ & $\begin{array}{c}\text { Post- } \\
\text { disturbance } \\
\text { (July 1997) }\end{array}$ & $\begin{array}{l}\text { Monitoring } \\
\text { (April 2001) }\end{array}$ \\
\hline Nematodes & 46 & 24 & 12 & 12 \\
\hline Copepods & 22 & 11 & 4 & 0.4 \\
\hline $\mathrm{N}: \mathrm{C}$ & 2.09 & 2.18 & 3 & 30 \\
\hline
\end{tabular}

\begin{tabular}{|c|c|c|c|c|c|c|}
\hline \multicolumn{7}{|c|}{$\begin{array}{l}\text { Table 5: Analysis of TWO-WAY variance of meiofaunal density between } \\
\text { the test and reference area }\end{array}$} \\
\hline $\begin{array}{l}\text { Source of } \\
\text { Variation }\end{array}$ & SS & df & MS & $\mathrm{F}$ & P-value & F crit \\
\hline Rows & 139.9412 & 16 & 8.746324 & 2.880378 & 0.000247 & 1.685795 \\
\hline Columns & 113.9853 & 15 & 7.59902 & 2.502543 & 0.001886 & 1.70823 \\
\hline Error & 728.7647 & 240 & 3.03652 & & & \\
\hline Total & 982.6912 & 271 & & & & \\
\hline
\end{tabular}




\section{Legends to text figures}

Fig. 1: Position of the sampling stations in INDEX area (counters is depths in $\mathrm{m}$.).

Fig. 2: Meiobenthic abundance $\left(\right.$ no. $\left.10 \mathrm{~cm}^{-2}\right)$ in individual core during three INDEX phases.

Fig. 3: Vertical distribution of meiofauna in test and reference area

Fig. 4: Vertical distribution and cumulative percentage of in test and reference area.

Fig. 5: Meiofaunal abundance $\left(n o .10 \mathrm{~cm}^{-2}\right.$ ) in CIB during different INDEX phases

Plate 1: Sub-sampling of meiofauna from box corer 


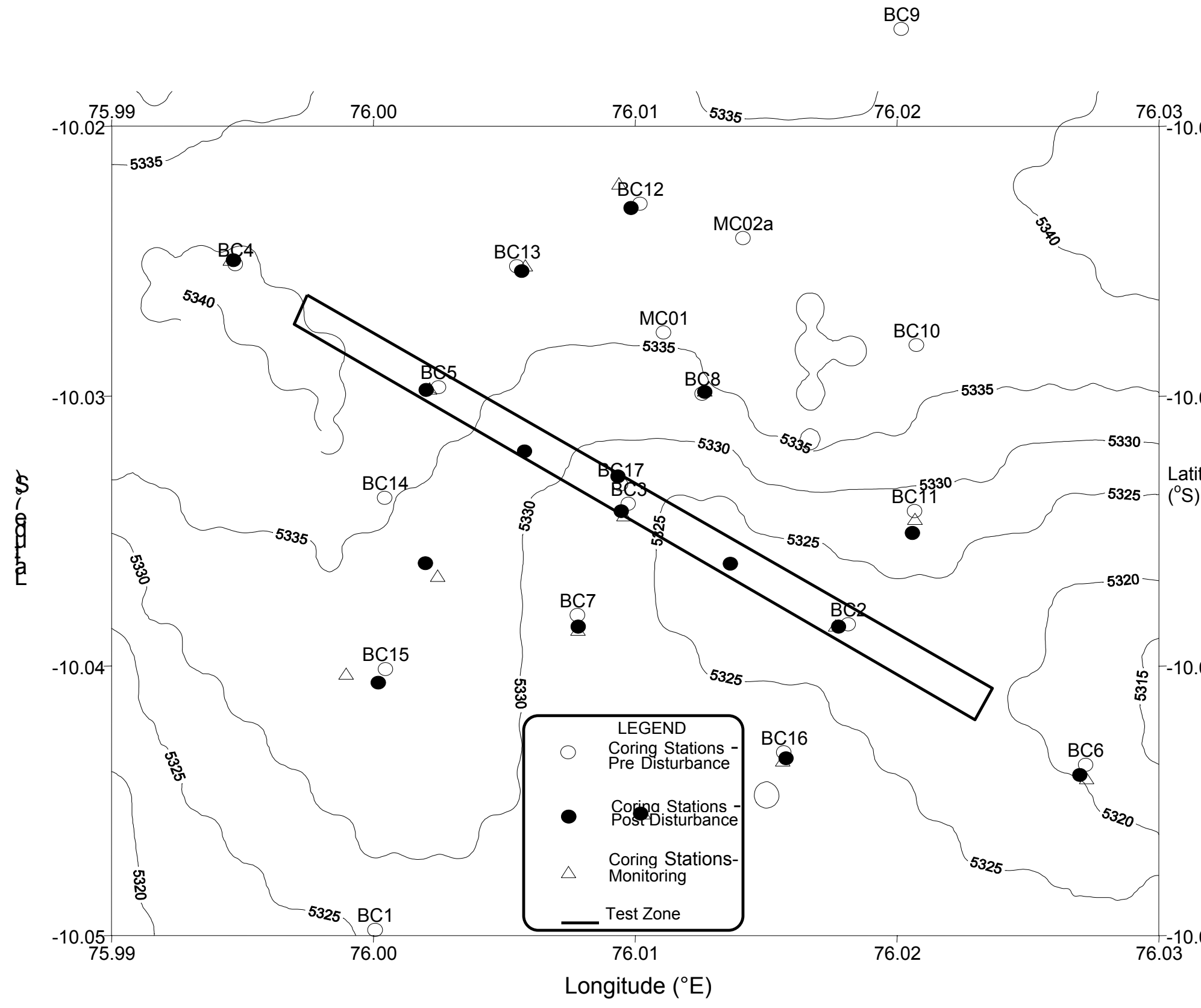

Fig. 1: Position of the sampling stations in INDEX area (counters: depths in $\mathrm{m}$ ). 


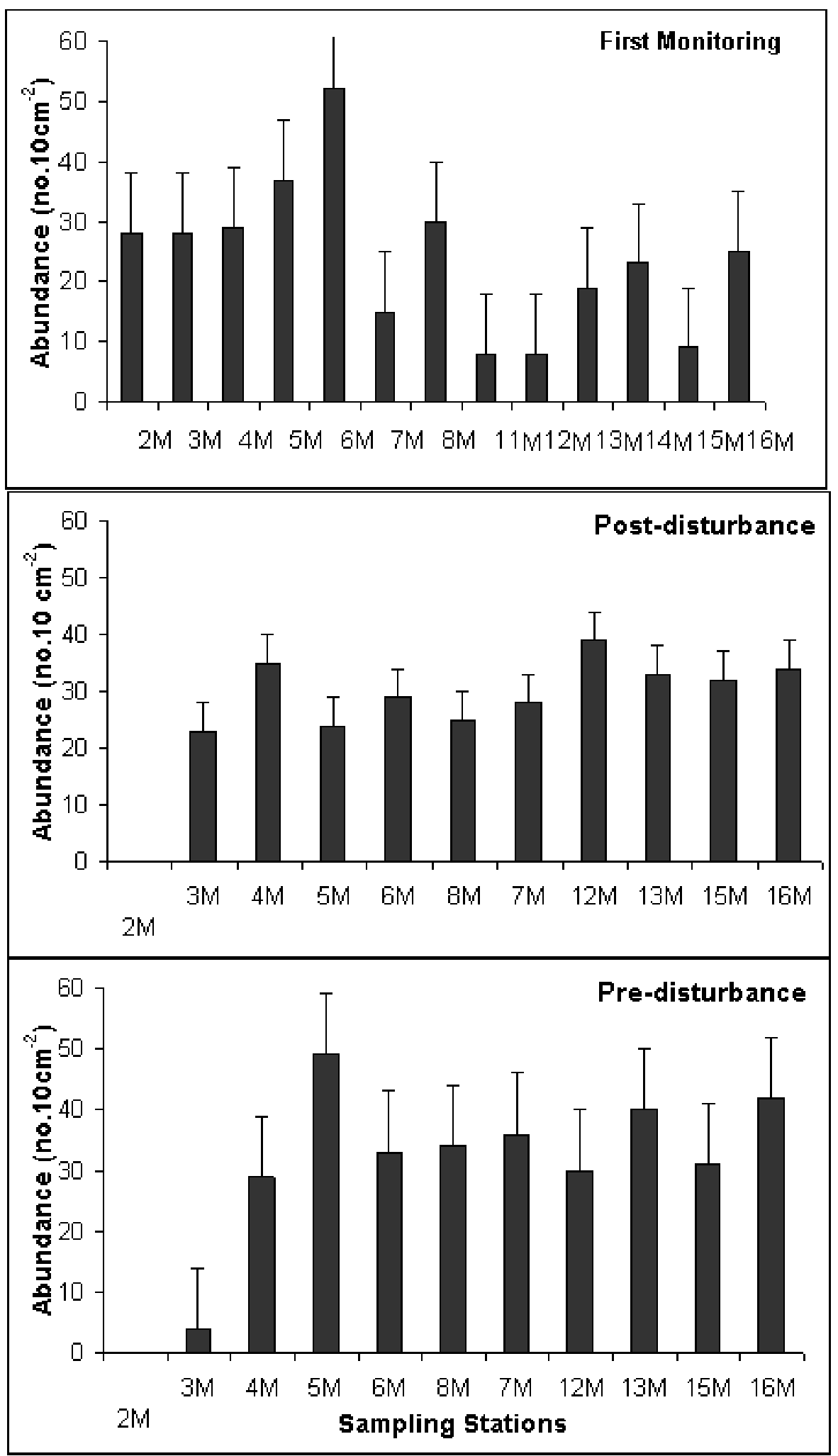

Fig. 2: Meiobenthic density $\left(\right.$ no.10 $\left.\mathrm{cm}^{-2}\right)$ in individual core during three INDEX phases. 

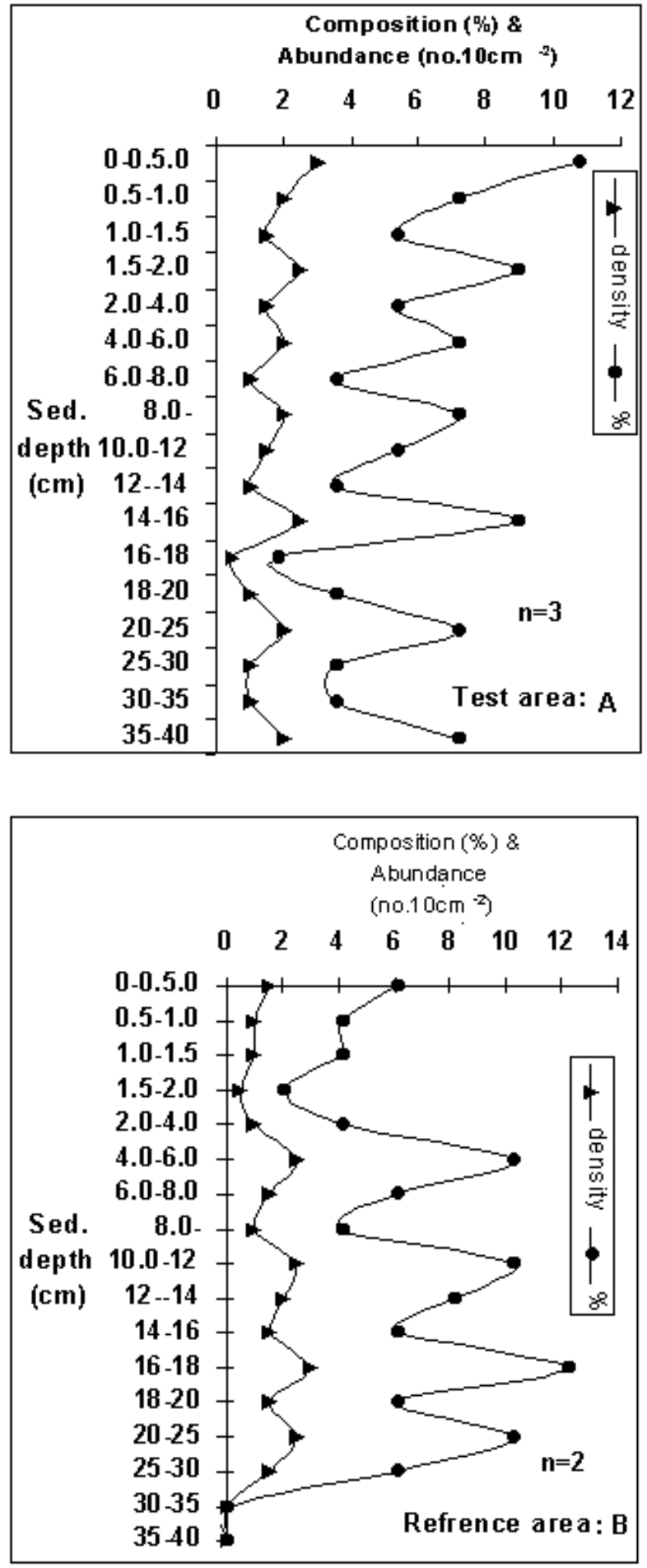

Fig. 3: Vertical distribution of meiofauna in test $(A)$ and reference area $(B)$ 


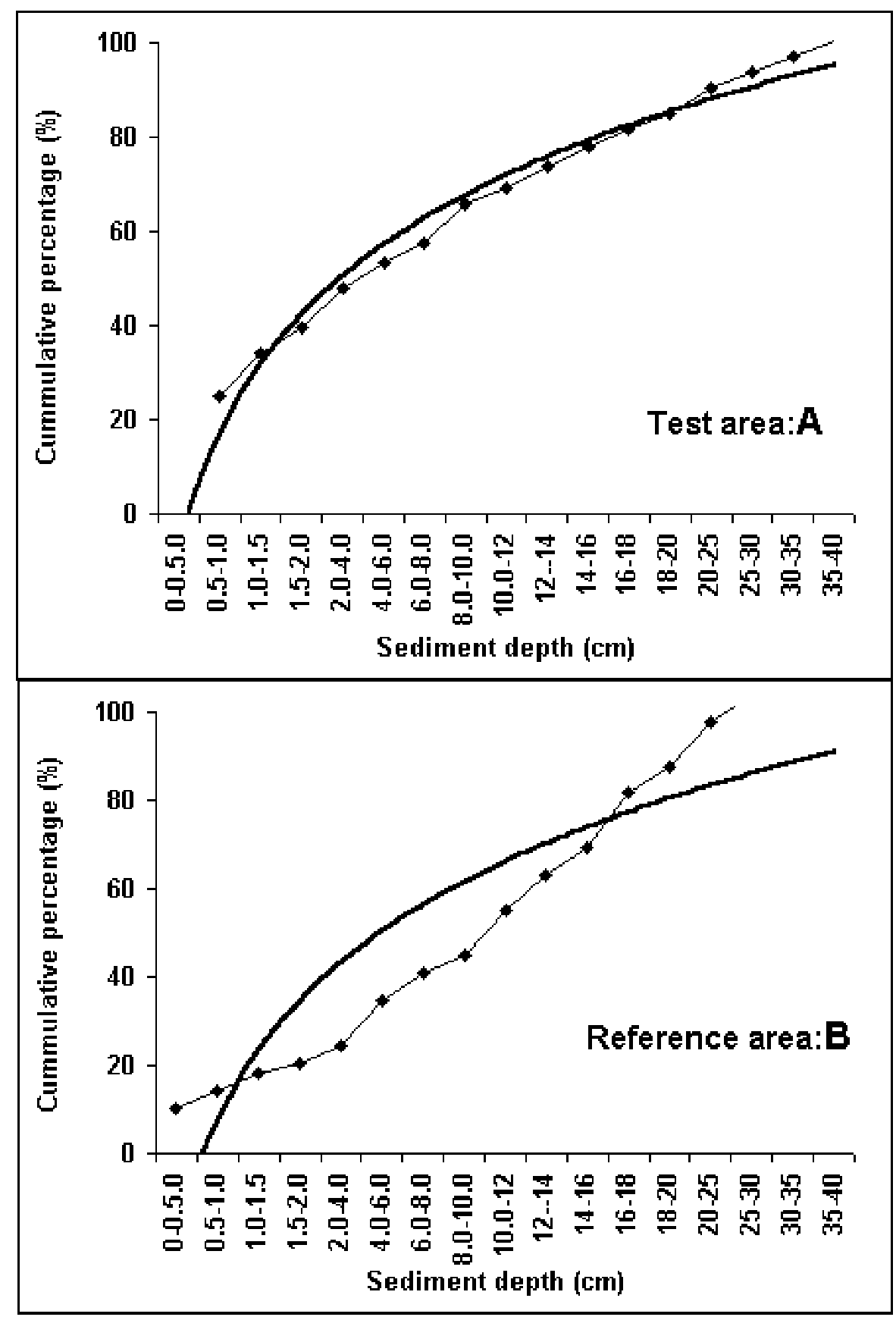

Fig.4: Cumulative percentage of meiofauna in test and reference area 

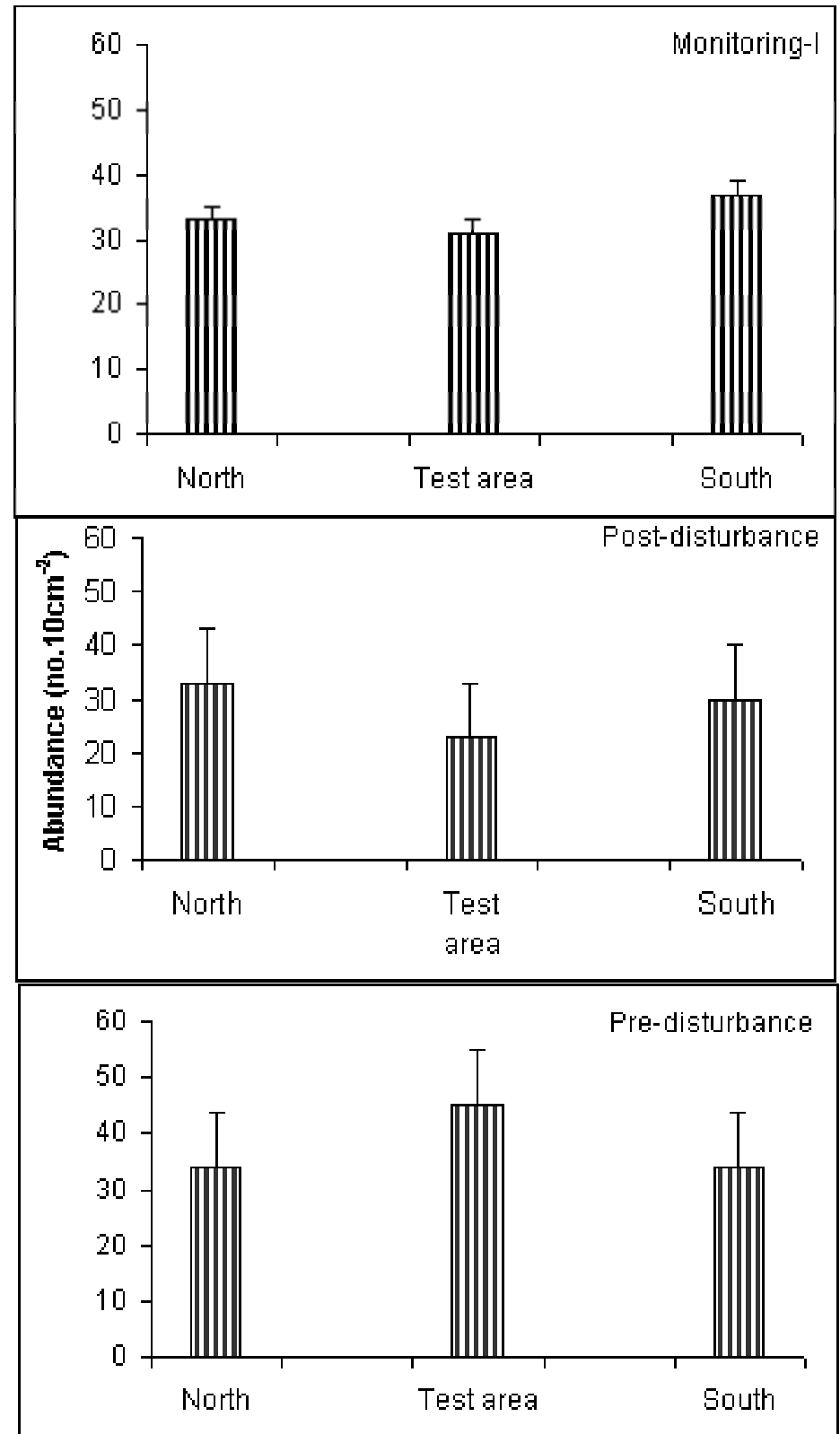

Fig. 5: Abundance $\left(\right.$ no. $10 \mathrm{~cm}^{-2}$ ) of meiofauna in CIB during three INDEX phases (North: north of the test area; South: south of the test area) 


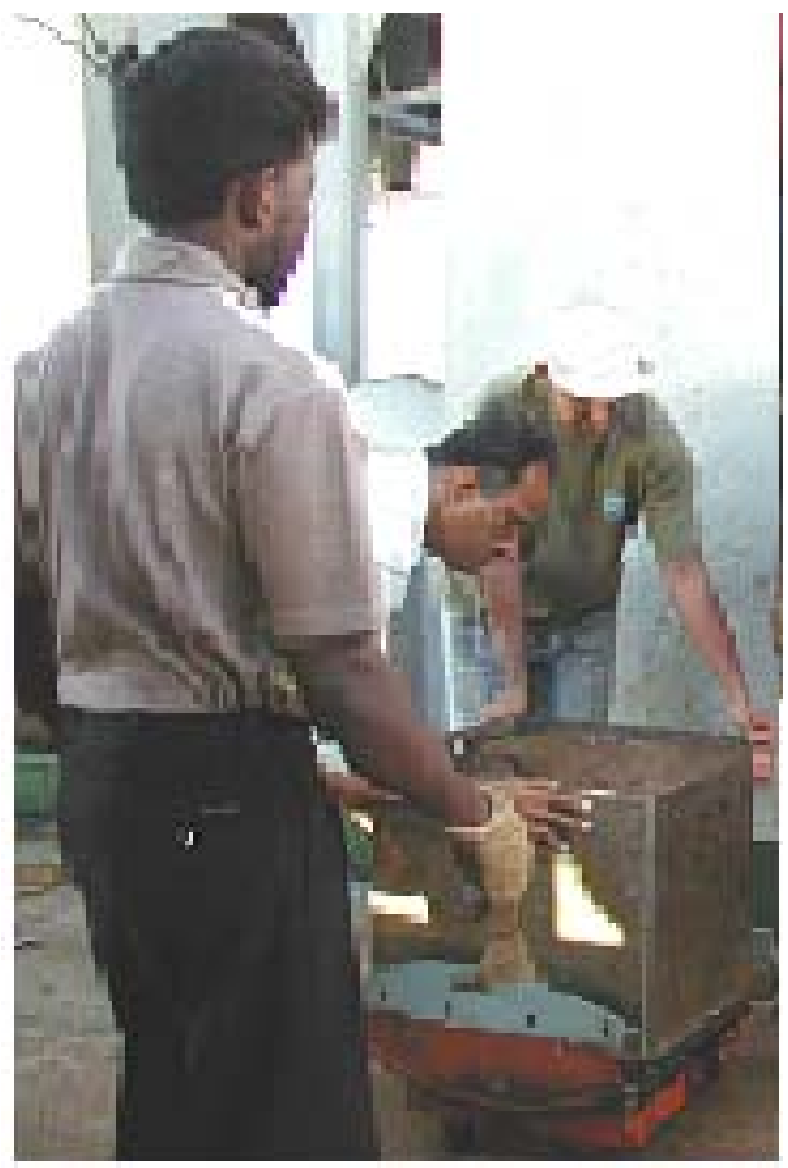

Plate 1: Box core sample being taken for sub-sampling 